\title{
RISK OF EMERGENCY SITUATIONS OF UNDERGROUND OBJECTS IN THE PERSPECTIVE OF MULTI-CRITERIA DECISION MAKING
}

\section{R. DACHOWSKI ${ }^{1}$, K. GALEK ${ }^{2}$}

The diaphragm wall and the open caisson represent two main competitive technologies used in the construction of underground objects. In modern times, diaphragm walls are primarily applied for large-size objects, with open caissons being preferred in the case of small-sized ones. Currently, objects of this type are designed mainly for sewage treatment plants and detention reservoirs. Their construction involves highly labour-intensive processes. During the execution of works unforeseen negative effects are observed to occur. During the underground objects construction the most common phenomena are: deviations from the vertical (tilt), sagging, sinking below the designed level, cracking, scratches or leakage through the wall. The purpose of the paper is to classify undesired risk factors emerging in the process of underground objects construction and selection of the optimal technological and material solution for municipal facilities. The implementation of this task involved the selection of Multi-Criteria Decision Making methods, taking into account the cause-effect rating, as the mathematical apparatus. The Ratio Estimation in Magnitudes or deciBells to Rate Alternatives which are Non-DominaTed (REMBRANDT) method was applied. The research proved that it is possible to analytically assess unforeseen risk factors conducive to emergency situations during the implementation of underground objects, using the REMBRANDT method.

Keywords: open caisson sinking, diaphragm wall, REMBRANDT, multi-criteria decision making, underground objects

\footnotetext{
${ }^{1}$ DSc., Kielce University of Technology, Faculty of Civil Engineering and Architecture , Al. Tysiąclecia Państwa Polskiego 7, 25-315 Kielce, Poland, e-mail: tobrd@tu.kielce.pl

${ }^{2}$ MSc., Kielce University of Technology, Faculty of Civil Engineering and Architecture , Al. Tysiąclecia Państwa Polskiego 7,

25-315 Kielce, Poland, e-mail: galekkatarzyna93@gmail.com
} 


\section{INTRODUCTION}

The development of modern cities together with the surrounding infrastructure and high urbanization is associated with the demand for new objects and traffic routes, which are increasingly located under the surface of the already developed area. A wide range of underground constructions and the complexity of implementation conditions, as well as the frequent negative impact on the technological process of underground objects may lead to preemergency or emergency situations. This results in the necessity to conduct a more complete classification of these objects, taking into account adverse risk factors associated with construction processes during the implementation of underground objects.

The official classification of underground objects divides them into linear and cubic [7]. Authors focus their attention on cubic objects. They are primarily designed to serve municipal, townplanning, industrial, hydro-technological and specialist purposes (military objects, hard coal mines). Currently, the most commonly constructed are the municipal objects. This is related to i.a. the Directive 91/271 /EEC [6] concerning municipal wastewater treatment. Pursuant to Article 43 (1) of the Water Act [19], agglomerations with PE of above 2,000 should have collective sewage systems with treatment plants for municipal sewage, in accordance with the provisions of the National Programme for Municipal Wastewater Treatment (NPMWT) [11]. This problem is related to the separation of stormwater from the sewage system. Introducing large amounts of stormwater into the river at once can pose a significant threat to the watercourse. Therefore, detention reservoirs are constructed with stormwater sewers. They perform the function of accumulation, as settlers in pump or gravity systems. In the face of serious climate change these systems are designed for many generations due to the frequent occurrence of hundred-year rainfalls [1]. The sewage pumping stations are built in typical wastewater treatment plants. Both detention reservoirs and sewage pumping stations are underground objects. In modern times the most commonly used underground objects technologies include: diaphragm walls, open caissons and combined methods (hybrids). The objective of the paper is to classify undesired risk factors emerging in the process of underground objects construction and selection of the optimal technological and material solution for municipal facilities. 


\section{CRITICAL LITERATURE ANALYSIS}

Information on the behavior of underground structures during the entire investment process was collected based on the analysis of the literature data as open caisson as data from the implementation of the underground objects, during which the authors of the article were participants in the implementation processes. As mentioned above, the most popular underground technologies today are diaphragm walls, open caissons and all hybrids, with the latter being performed in principle for open excavations. The authors dealt with the analysis of technologies implemented without the need to perform open excavations. They analyzed the technology of the diaphragm wall and open caisson. Practically, the implementation of the underground objects for economic reasons takes place in underground technologies from a depth of about 6-8 $\mathrm{m}$. Analyzing the entire implementation process of the diaphragm wall and open caissons we deal with the following risk factors:

$>$ tilting,

$>$ hanging,

$>$ implementation below the designed level,

$>$ floating objects above the foundation level,

$>$ cracking of reinforced concrete wall,

$>$ freezing of the external surface of the reinforced concrete wall to the surrounding soil.

\subsection{CRITICAL LITERATURE ANALYSIS OF DIAPHRAGM WALL TECHNOLOGY}

Pakbaz M.S. [18] in his article assesses the effect of soil excavation after the construction of a diaphragm wall at the depth of $5.0 \mathrm{~m}$ (designed depth - $17.5 \mathrm{~m}$ ). He measured the lateral deviations of the diaphragm walls and the settlement of the ground surface behind the wall at the underground station in Iran, with the measurements being performed in three stages. The lateral deviations of the wall were of about $4 \mathrm{~cm}$, while those of the surface behind the wall at a distance of 5,10 and $15 \mathrm{~m}$ - from 4 to $12 \mathrm{~cm}$. Then, lateral deviations of the walls and the settlement of the surface were estimated by numerical methods at a distance of up to $50 \mathrm{~m}$, comparing with data from all over the world. The forecasts were optimistic, but still the surface damage to the neighbouring buildings was predicted. The article [21] presents an overview of various methods of verifying the stability of diaphragm wall and the terrain surface and compares them with two diaphragm walls with a depth of $30 \mathrm{~m}$ in Bucharest. The papers [23, $24]$ were devoted to the pressure of the concrete mixture on the surface of the slurry trench and 
the resulting deformations. It was found that laying the concrete mix increases the passive soil pressure and causes a significant increase in the level of stress in the upper part of the wall. As a result of the increased stress prior to soil excavation, up to $15 \%$ larger deformation of the terrain surface and wall deformation is predicted. The article [25] deals with the problem of deformation of the diaphragm wall in the construction of the Berlin underground and the impact of this phenomenon on the surrounding overground objects. It was found that the evaluation of this phenomenon should be performed using simple numerical methods, due to permanent changes in technological processes over time. Authors in [16] concluded that the impact zone on the surface of the terrain behind the wall, which has effect on the deformation of the diaphragm wall, is equal to its depth, D. A settlement zone is formed behind the wall. The maximum settlement is about $0.2 \mathrm{D}$ behind the wall, and the settlement outside the impact zone is negligible.

\subsection{CRITICAL LITERATURE ANALYSIS OF OPEN CAISSON TECHNOLOGY}

The article [14] presents the design procedure, construction methodology and difficulties encountered during the construction of a rectangular-section open caisson for pumping stations intended for irrigation systems in India. The article [23] presents the design procedure, construction methodology and difficulties encountered during the construction of a rectangularsection caisson for pumping stations intended for irrigation systems in India. The soil consisted of sandy clayey silt, with the layer of rock starting at the depth of $30 \mathrm{~m}$. Those conditions were difficult, so with a high level of groundwater, the construction of the caisson became a compiled task, due to the excavation of the soil from under the water, which is associated with the danger of inclinations. Many articles emphasize the need for thorough soil investigation $[3,5,13]$. For example, the article [3] discusses the use of vertical seismic profiling in geological-geophysical soil research. The given solutions are connected with the use of sophisticated equipment, used primarily for very large investments, and unfortunately - not very precise. Owing to the above, simpler soil investigation methods are often used in the implementation of underground objects [3]. Another issue in the construction of underground objects using the open caisson technology is the continuous monitoring of the implementation process, with the application of various types of software and many sensors. This method undoubtedly allows for an increased hazard during the implementation of underground objects. It also reduces the risk factors on structures, but it is considerably more costly. In the applications of this technology discussed in this article, i.e. during the construction of sewage pumping stations or small-sized detention reservoirs, this 
may significantly increase costs. This is undoubtedly future-oriented methodology, however, it is appropriate for large-scale objects and unfortunately requires a huge amount of data from nature [9].

\subsection{DATA AND METHODOLOGY}

The analytical process was based on the use of a multi-criteria decision making apparatus. For this analysis to be conducted, the previously presented literature review was used. This provided basis for the selection of the criteria for individual technological and construction solutions together with risk factors (table 1). The criterion of economy remains without a description of negative impact. Instead, a graph has been presented (Figure 1). The multi-criteria analysis, carried out in the next part focuses on the construction of underground facilities at a depth of $6 \mathrm{~m}$.

Tabela 1. Negative impact on the implementation process of underground objects.

\begin{tabular}{|c|c|c|c|}
\hline \multirow{3}{*}{ No. } & \multirow{3}{*}{ Criteria } & \multicolumn{2}{|c|}{ Technological and structural solutions } \\
\hline & & Diaphragm wall (DW) & Open caisson $(\mathrm{OC})$ \\
\hline & & \multicolumn{2}{|c|}{ Negative impact } \\
\hline 1 & Economy (EC) & $\mathrm{n} / \mathrm{d}$ (no data) & $\mathrm{n} / \mathrm{d}$ (no data) \\
\hline 2 & Soil excavation (SE) & $\begin{array}{l}\text { - wall deviation from the vertical, } \\
\text { - arch deflection of the walls, } \\
\text { - ground settlement behind the wall, } \\
\text { - landslides, } \\
\text { - increased excavation of soil mass } \\
\text { - wall cracks, scratches }\end{array}$ & $\begin{array}{l}\text { - wall deviation from the vertical } \\
\text { - ground settlement behind the wall, } \\
\text { - increased excavation of soil mass }\end{array}$ \\
\hline 3 & $\begin{array}{l}\text { Placing concrete moz } \\
\text { (PCM) }\end{array}$ & $\begin{array}{c}\text { - increased pressure of the concrete } \\
\text { mix on the walls of the slurry } \\
\text { trench, } \\
\text { - increased amount of the applied } \\
\text { concrete mixture } \\
\text { - roughness of the concrete surface, } \\
\text { - the possibility of imprecise concrete } \\
\text { mix laying }\end{array}$ & - roughness of the concrete surface, \\
\hline 4 & $\begin{array}{l}\text { Deviation from the } \\
\text { vertical(VD) }\end{array}$ & - wall scratches and cracks, & $\begin{array}{l}\text { - wall scratches and cracks, } \\
\text { - the possibile appearance of } \\
\text { increased quantities of soil } \\
\text { masses in the caisson, }\end{array}$ \\
\hline
\end{tabular}




\section{Comparison of underground municipal facilities}

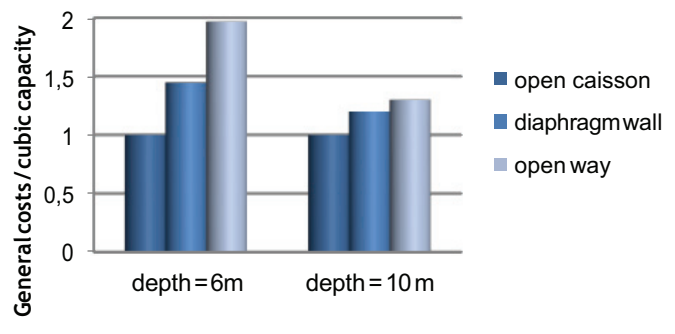

Fig.1. Comparison of costs for three technologies of underground municipal objects.

With the application of the operational research, the multicriteria decision support methods permit the selection of the optimal solution out of many decision variants. The most favourable option is chosen on the basis of uniform criteria applied to assess individual solutions. In certain multicriteria methods the solutions are assessed based on defined scales [9,18]. The Analytic Hierarchy Process is a multicriteria decision support method which uses the utility function, similarly to the REMBRANDT method. The AHP uses Saaty's 1-9 scale [8,22,26,27]. Ratio Estimation in Magnitudes or deci-Bells to Rate Alternatives which are Non-DominaTed Technika (REMBRANDT) was developed in Holand under the supervision of Lootsma (1992). REMBRANDT hierarchy is divided into three levels. The highest level comprises the objective of the analysis, the lower level includes the criteria and the bottom of the hierarchy - decision variants $[15,28]$. The element comparison results are determined on the basis of the logarithmic rating scale (Tab.1.) $[2,12,15]$. The scale is constructed in a way that eliminates the reversed rating problem that may occur in the case of AHP [17,29]. 
Table 2. Rating scale for the REMBRANDT method [15].

\begin{tabular}{|c|c|}
\hline Descriptive assessment & $\begin{array}{c}\text { Numerical } \\
\text { assessment }\end{array}$ \\
\hline Huge advantage of the second in turn variant over the first one. & -8 \\
\hline Intermediate rating & -7 \\
\hline Very big advantage of the second in turn variant over the first one. & -6 \\
\hline Intermediate rating & -5 \\
\hline Big advantage of the second in turn variant over the first one. & -4 \\
\hline Intermediate rating & -3 \\
\hline Slight advantage of the second in turn variant over the first one. & -2 \\
\hline Intermediate rating & -1 \\
\hline Equivalence of elements & 0 \\
\hline Intermediate rating & 1 \\
\hline Intermediate rating over the second one. & 2 \\
\hline Big advantage of the first in turn variant over the second one. & 3 \\
\hline Intermediate rating & 4 \\
\hline Very big advantage of the first in turn variant over the second one. & 5 \\
\hline Intermediate rating & 6 \\
\hline Huge advantage of the first in turn variant over the second one. & 7 \\
\hline
\end{tabular}

The first stage of the analysis using the REMBRANDT method is to create a matrix of comparisons of criteria pairs, according to the scale presented above. Subsequently, the values of the matrix are converted into values of the geometric scale, according to the formula (2.1) [28]:

$$
\frac{d_{i}}{d_{j}}=\exp \left(\gamma \delta_{i j}\right), \quad i, j=1, \ldots, z \quad \gamma=\ln \sqrt{2}
$$

Next, the geometric means $\left(\mathrm{v}_{\mathrm{i}}\right)$ for each of the rows of the obtained matrix (2.2) are determined [29].

$$
v_{i}=\sqrt[n]{K_{1} \cdot K_{2} \cdot K_{3} \cdot K_{4} \cdot \ldots \cdot K_{n}} \text {, where } \mathrm{n} \text { - number of criteria, } \mathrm{K}_{\mathrm{n}} \text {-criteria }
$$

The obtained geometric means are successively normalized additively $\left(\mathrm{v}_{\mathrm{i}}{ }^{\prime}\right)(2.3)$ [15]. The normalization process is completed when the weights for each criterion have been achieved.

$$
v_{i}^{\prime}=\frac{v_{i}}{\sum_{j=1}^{n} v_{i, j}}
$$

The second stage of the analysis involves determining the comparison matrix in pairs of decision variants with respect to each of the criteria. The remaining procedures include the 
transformation of the comparison matrix in pairs of decision variants into the values of the geometrical scale, the calculation of geometric means for individual rows and additive normalization. The third stage consists in calculating the final priority values for all the decision variants $\left(\mathrm{s}_{\mathrm{i}}\right)$ (2.4). The weights previously determined for the criteria are used for calculations.

$$
s_{i=\prod_{k=1}^{n}\left(V^{\prime} j . i\right)} s K_{j}
$$

The result of calculations is the matrix - the rating of decision variants.

\section{RESULTS OF ANALYSIS}

After determining the relations between the criteria, a comparison matrix of criteria was built in accordance with the REMBRANDT methodology (Fig.2.). The following designations were used: K1 - economy (EC), K2 - soil excavation (SE), K3 - placing concrete mix (PCM), K4 vertical deflection (VD).

\begin{tabular}{|c|c|c|c|c|}
\hline $\boldsymbol{\delta}_{\mathbf{i j}}$ & $\mathbf{K}_{\mathbf{1}}$ & $\mathbf{K}_{\mathbf{2}}$ & $\mathbf{K}_{\mathbf{3}}$ & $\mathbf{K}_{\mathbf{4}}$ \\
\hline $\mathbf{K}_{\mathbf{1}}$ & 0 & -5 & -4 & 6 \\
\hline $\mathbf{K}_{\mathbf{2}}$ & 5 & 0 & 4 & 0 \\
\hline $\mathbf{K}_{\mathbf{3}}$ & 4 & -4 & 0 & 0 \\
\hline $\mathbf{K}_{\mathbf{4}}$ & -6 & 0 & 0 & 0 \\
\hline
\end{tabular}

Fig.2. Matrix of criteria comparisons.

Subsequently established values were transformed into geometric scale values. The transformations resulted in the following matrix (Fig.3.).

\begin{tabular}{|c|c|c|c|c|}
\hline $\boldsymbol{\delta}_{\mathbf{i j}}$ & $\mathbf{K}_{\mathbf{1}}$ & $\mathbf{K}_{\mathbf{2}}$ & $\mathbf{K}_{\mathbf{3}}$ & $\mathbf{K}_{\mathbf{4}}$ \\
\hline $\mathbf{K}_{\mathbf{1}}$ & 1 & 0.177 & 0.25 & 8 \\
\hline $\mathbf{K}_{\mathbf{2}}$ & 5.657 & 1 & 4 & 1 \\
\hline $\mathbf{K}_{\mathbf{3}}$ & 4 & 0.25 & 1 & 1 \\
\hline $\mathbf{K}_{\mathbf{4}}$ & 0.125 & 1 & 1 & 0 \\
\hline
\end{tabular}

Fig.3. Matrix of criteria comparisons with the geomentric scale values.

Next, the geometric means for each of the rows was determined (Fig. 4) and the data were subject to additive normalization, as shown in Fig.5. 


\begin{tabular}{|c|c|c|c|c|c|}
\hline $\boldsymbol{\delta}_{\mathbf{i j}}$ & $\mathbf{K}_{\mathbf{1}}$ & $\mathbf{K}_{\mathbf{2}}$ & $\mathbf{K}_{\mathbf{3}}$ & $\mathbf{K}_{\mathbf{4}}$ & $\mathbf{V}_{\mathbf{i}}$ \\
\hline $\mathbf{K}_{\mathbf{1}}$ & 1 & 0.177 & 0.25 & 8 & 0.771 \\
\hline $\mathbf{K}_{\mathbf{2}}$ & 5.657 & 1 & 4 & 1 & 2.181 \\
\hline $\mathbf{K}_{\mathbf{3}}$ & 4 & 0.25 & 1 & 1 & 1 \\
\hline $\mathbf{K}_{\mathbf{4}}$ & 0.125 & 1 & 1 & 0 & 0.595 \\
\hline
\end{tabular}

Fig.4. Matrix after determining the geometric mean.

\begin{tabular}{|c|c|c|c|c|c|}
\hline $\boldsymbol{\delta}_{\mathbf{i j}}$ & $\mathbf{K}_{\mathbf{1}}$ & $\mathbf{K}_{\mathbf{2}}$ & $\mathbf{K}_{\mathbf{3}}$ & $\mathbf{K}_{\mathbf{4}}$ & $\mathbf{V}_{\mathbf{i}}{ }^{\prime}$ \\
\hline $\mathbf{K}_{\mathbf{1}}$ & 1 & 0.177 & 0.25 & 8 & 0.771 \\
\hline $\mathbf{K}_{\mathbf{2}}$ & 5.657 & 1 & 4 & 1 & 2.181 \\
\hline $\mathbf{K}_{\mathbf{3}}$ & 4 & 0.25 & 1 & 1 & 1 \\
\hline $\mathbf{K}_{\mathbf{4}}$ & 0.125 & 1 & 1 & 0 & 0.595 \\
\hline
\end{tabular}

Fig.5. Normalized matrix.

In the second stage of the REMBRANDT analysis, a matrix of comparisons of decision variants against the previously defined criteria was created. The following matrices were obtained:

\begin{tabular}{|c|l|l|}
\hline $\boldsymbol{\delta}_{\mathrm{ij}}$ & $\mathbf{O C}$ & $\mathbf{D W}$ \\
\hline $\mathbf{O C}$ & 0 & 4 \\
\hline $\mathbf{D W}$ & -4 & 0 \\
\hline
\end{tabular}

Fig.6. Matrix of comparisons of decision variants against the criterion of $\mathrm{K} 1$ - economy.

\begin{tabular}{|c|l|l|}
\hline$\delta_{i j}$ & OC & DW \\
\hline OC & 0 & 4 \\
\hline DW & -4 & 0 \\
\hline
\end{tabular}

Fig.8. Matrix od comparisons of decision variants against criterion of $\mathrm{K} 3$ - soil laying excavation.

\begin{tabular}{|c|l|l|}
\hline$\delta \mathbf{i j}$ & OC & DW \\
\hline OC & 0 & 8 \\
\hline DW & -8 & 0 \\
\hline
\end{tabular}

Fig.7. Matrix of comparison of decision variants against the criterion of $\mathrm{K} 2$ - deviation from the vertical.

\begin{tabular}{|c|l|l|}
\hline$\delta_{i j}$ & OC & DW \\
\hline OC & 0 & 4 \\
\hline DW & -4 & 0 \\
\hline
\end{tabular}

Fig.9. Matrix od comparisons of decision variants against criterion of $\mathrm{K} 4$ concrete mix.

Used symbols: OP-open caisson, DW-diaphragm wall.

The subsequent procedures were analogous to the criteria analysis. The matrix values were transformed into geometric scale values, the geometric means of the rows were calculated and the obtained results were normalized according to the formula (1.5).

The result of normalization is shown in Figures 10-13 
(3.1)

$$
s K_{i}=\frac{v_{i}}{\sum_{j=1}^{n} v_{i, j}}
$$

\begin{tabular}{|l|l|c|c|}
\hline$\delta_{i j}$ & $\mathbf{O P}$ & $\mathbf{D W}$ & $\mathbf{s K}_{\mathbf{i}}$ \\
\hline $\mathbf{O P}$ & 0 & 4 & 0.8 \\
\hline $\mathbf{D W}$ & -4 & 0 & 0.2 \\
\hline
\end{tabular}

Fig.10. Matrix of comparisons of decision variants after normalization

\begin{tabular}{|l|l|l|l|}
\hline$\delta_{i j}$ & OP & DW & $\mathbf{s K}_{\mathbf{i}}$ \\
\hline OP & 0 & 4 & 0.8 \\
\hline $\mathbf{D W}$ & -4 & 0 & 0.2 \\
\hline
\end{tabular}

Fig.12. Matrix of comparisons of decisio variants after normalization.

\begin{tabular}{|r|l|l|l|}
\hline $\boldsymbol{\delta}_{\mathbf{i j}}$ & $\mathbf{O P}$ & $\mathbf{D W}$ & $\mathbf{s K}_{\mathbf{i}}$ \\
\hline $\mathbf{O P}$ & 0 & 8 & 0.941 \\
\hline $\mathbf{D W}$ & -8 & 0 & 0.059 \\
\hline
\end{tabular}

Fig.11. Matrix of comparisons of decision variants after normalization.

\begin{tabular}{|l|l|l|l|}
\hline $\boldsymbol{\delta}_{\mathbf{i j}}$ & $\mathbf{O P}$ & $\mathbf{D W}$ & $\mathbf{s K}_{\mathbf{i}}$ \\
\hline $\mathbf{O P}$ & 0 & 4 & 0.8 \\
\hline $\mathbf{D W}$ & -4 & 0 & 0.2 \\
\hline
\end{tabular}

Fig.13. Matrix of comparisons of decision variants after normalization.

The final stage was to determine the final vector of priorities (Fig.14).

$$
\begin{aligned}
& S_{1}=0.8^{0.17} \cdot 0.941^{0.48} \cdot 0.8^{0.22} \cdot 0.8^{0.131} \\
& S_{2}=0.2^{0.17} \cdot 0.059^{0.48} \cdot 0.2^{0.22} \cdot 0.2^{0.131}
\end{aligned}
$$

\begin{tabular}{|l|l|}
\hline $\begin{array}{l}\mathbf{S}_{\mathbf{1}} \\
\text { (OP) }\end{array}$ & 0.865 \\
\hline $\begin{array}{l}\mathbf{S}_{2} \\
\text { (DW) }\end{array}$ & 0.111 \\
\hline
\end{tabular}

Fig.14. Final vector of priorities.

The first solution - the open caisson - obtained a higher value of the final vector of priorities (OP) -0.865 . The REMBRANDT analysis revealed that the open caisson offers a better technology, material and construction solution. 


\section{CONCLUSIONS}

The critical analysis of the literature, together with the available data obtained from practical execution of works, concerning cubic underground structures intended for municipal use, allowed for the identification of technological and construction solutions appropriate for sewage pumping stations in sewage treatment plants as open caisson as detention reservoirs.

Taking into account technology, construction and materials, the solutions selected for detailed analysis, chosen out of numerous available variants of underground objects, included diaphragm walls, open caissons, open excavations with various temporary casings characteristic for previously used applications.

A multi-criteria analysis and assessment of risk factors on the execution of selected technological and construction variants were performed, and the uniform criteria from the primary groups: technological, construction and economic were established. With the predetermined number of three technology, construction and material solutions, the following secondary criteria were selected: placing concrete moz (PCM), soil excavation (SE), deviation from the vertical (VD) and economy (EC).

The method of multi-criteria support of the decision-making process - REMBRANDT made it possible to calculate weights for each of the criteria based on a hierarchical scale. The applied REMBRANDT methodology allowed for the determination which of the considered technological, constructional and material solutions for municipal objects was optimal.

The first variant, i.e. the open caisson, achieved better results. The REMBRANDT method indicates the best solution for a chosen decision problem. The method does not allow for revealing relations between criteria and cases.

\section{REFERENCES}

1. B. Ambroża-Urbanek, Rozdzielność sieci - szanse i nowe trendy w kanalizacji. Dyskusja z Nalaskowskim J. i Dziopakiem J. Nowoczesne Budownictwo Inżynieryjne. 2010, Nr 1-2, s. 68-71.

2. M. B. Baefod and S. Leleur, "Scaling Transformation in the Rembrandt Technique: Examination of the Progression Factors,” Int. J. Inf. Technol. Decis. Mak., vol. 12, no. 05, pp. 887-903, 2013.

3. V.N.Beskopylny, V.V.Rishtovsky, V.M.Gromyko, Complex technology of operative geological-geophysical support of wells sinking Neftyanoe khozyaystvo - Oil IndustryIssue 11, November 2004, Pages 30-33

4. J. Brzostowski, E. Roszkowska, and T. Wachowicz, "Using an Analytic Hierarchy Process to develop a scoring system for a set of continuous feasible alternatives in negotiation,” Oper. Res. Decis., vol. 4, no. 4, pp. 21-40, 2012.

5. R. Dachowski, The influence of sinking underground structures or foundations by the caisson method on the surrounding ground mass and neighboring buildings, proceedings of the ninth danube-european conference on soil mechanics and foundation engineering Pages: 313-318 Published: 1990.

6. Dyrektywa nr 91/271/EEC w sprawie oczyszczania ścieków komunalnych. 
7. S. Gałczyński, “Budowle podziemne”, Zarys projektowania I wykonawstwa, Wrocław, 1979.

8. J. Harasymiuk, E. Szafranko, and J. A. Pawłowicz, "Research on the possibilities of building in Natura 2000 sites in Poland on the example of Warmia and Mazury Province,” Adv. Eng. Res., no. July, pp. 1550-1554, 2018.

9. S. A. Hosseini, A. Akbarpour, H. Ahmadi, and B. Aminnejad, "Balance of Cost, Time, and Quality Related to Construction Projects Regarding the Reinforced Concrete of Underground Structures using a Meta-Heuristic Algorithm," Arch. Civ. Eng., 2017.

10. Huang, Xingchun, Kou, Xinjian, Lin, Lin "Visual measurement of Large scale well-sinking by means of close- up photogrammetry Shanghai", Jiaotong Daxue Xuebao/Journal of Shanghai Jiaotong University 33(6), pp. 742- 745,1999.

11. Krajowy Program Oczyszczania Ścieków Komunalnych. Ministerstwo Środowiska. Warszawa, grudzień 2003.

12. M. Modiri, M. B. Aryanezhad, and H. Maleki, "A Comparison of the REMBRANDT System with a New Approach in AHP,” J. Ind. Eng., vol. 6, pp. 7-12, 2010.

13. E.E.Mordovets, Permyakov, V.Yu, D.B.Shkol'nikov, L.M.Geukharov, Sinking a prefabricated reinforcedconcrete well in a thixotropic jacketSoil Mechanics and Foundation EngineeringVolume 7, Issue 3, May 1970, Pages 185-187

14. J.M.Mulay, Large size rectangular well foundation for pump houses by well sinking technique Indian Concrete Journal Volume 82, Issue 4, April 2008, Pages 44-48

15. K. Nermend, Metody analizy wielokryterialnej i wielowymiarowej we wspomaganiu decyzji. 2017.

16. C. W. W. Ng and R. W. M. Yan, "Stress Transfer and Deformation Mechanisms around a Diaphragm Wall Panel," J. Geotech. Geoenvironmental Eng., 1998.

17. D. L. Olson, G. Fliedner, and K. Currie, "Comparison of the REMBRANDT system with analytic hierarchy process,” Eur. J. Oper. Res., 1995.

18. M. S. Pakbaz, S. Imanzadeh, and K. H. Bagherinia, "Characteristics of diaphragm wall lateral deformations and ground surface settlements: Case study in Iran-Ahwaz metro,” Tunn. Undergr. Sp. Technol., 2013.

19. Prawo Wodne. Ustawa z dn. 18 lipca 2001 Dz.U. nr 115, poz.1229 (z późn. zmian.).

20. E. Radziszewska-Zielina, E. Kania, and G. Śladowski, "Problems of the Selection of Construction Technology for Structures in the Centres of Urban Agglomerations," Arch. Civ. Eng., 2018.

21. Raileanu, Calculations versus measurements of the diaphragm wall trench stability and of the deformations. Advances in Soil Mechanics and Geotechnical Engineering, 2, 572-575, 2013.

22. T. L. Saaty, "Decision making with the analytic hierarchy process," Int. J. Serv. Sci., 2008.

23. H. Schad, P. Vermeer, and A. Lächler, "Fresh concrete pressure in diaphragm wall panels and resulting deformations," Adv. Constr. Mater. 2007, 2007.

24. R. Schäfer and T. Triantafyllidis, "The influence of the construction process on the deformation behaviour of diaphragm walls in soft clayey ground,” Int. J. Numer. Anal. Methods Geomech., 2006.

25. L. Speier, S. Görtz, and U. Schran, "Metro line U5 Berlin - Deformation of diaphragm walls," Proc. Int. Conf. Numer. Simul. Constr. Process. Geotech. Eng. Urban Environ., 2006.

26. E. Szafranko, "Applicability of multi-criteria analysis methods for the choice of material and technology solutions in building structures," Teh. Vjesn. - Tech. Gaz., vol. 24, no. 6, 2017.

27. E. Szafranko, "Application of multi-criterial analytical methods for ranking environmental criteria in an assessment of a development project,"J. Ecol. Eng., 2017.

28. T. Trzaskalik, "Wielokryterialne wspomaganie decyzji. Przegląd metod i zastosowań," Zesz. Nauk. Politech. Śląskiej. Ser. Organ. i Zarządzanie, 2014.

29. R. C. Van Den Honert and F. A. Lootsma, "Assessing the quality of negotiated proposals using the REMBRANDT system,” Eur. J. Oper. Res., 2000.

\section{LIST OF FIGURES AND TABLES:}

Tabela 1. Negative impact on the implementation process of underground objects. Tabela 1.

Negatywne oddziaływania na proces realizacyjny obiektów podziemnych. Fig.1.

Comparison of costs for three technologies of underground municipal objects. Fig.1.

Porównanie kosztów dla trzech technologii podziemnych obiektów komunalnych. Table 2 .

Rating scale for the REMBRANDT method. [14].

Tabela 2. Skala ocen dla metody REMBRANDT [14].

Fig.2. Matrix of criteria comparisons. 
Fig.2. Macierz porównań kryteriów.

Fig.3. Matrix of criteria comparisons with the geomentric scale values.

Fig.3. Macierz porównań kryteriów, z wartościami skali geometrycznej.

Fig.4. Matrix after determining the geometric mean.

Fig.4. Macierz po wyznaczeniu średniej geometrycznej.

Fig.5. Normalized matrix.

Fig.5. Znormalizowana macierz.

Fig.6. Matrix of comparisons of decision variants against the criterion of K1 - economy. Fig.6.

Macierz porównań wariantów decyzyjnych względem kryterium K1 - ekonomia.

Fig.7. Matrix of comparisons of decision variants against the criterion of $\mathrm{K} 2$ - deviation from the vertical.

Fig.7. Macierz porównań wariantów decyzyjnych względem kryterium K2 - odchylenie od pionu.

Fig.8. Matrix od comparisons of decision variants against criterion of K3 - soil excavation.

Fig.8. Macierz porównań wariantów decyzyjnych względem kryterium K3 - urabianie gruntu. Fig.9.

Matrix od comparisons of decision variants against criterion of K4 - laying concrete mix. Fig.9.

Macierz porównań wariantów decyzyjnych względem kryterium K4 - układanie mieszanki betonowej.

Fig.10. Matrix of comparisons of decision variants after normalization.

Fig.10. Macierz porównań wariantów decyzyjnych po normalizacji.

Fig.11. Matrix of comparisons of decision variants after normalization.

Fig.11. Macierz porównań wariantów decyzyjnych po normalizacji.

Fig.12. Matrix of comparisons of decision variants after normalization.

Fig.12. Macierz porównań wariantów decyzyjnych po normalizacji.

Fig.13. Matrix of comparisons of decision variants after normalization.

Fig.13. Macierz porównań wariantów decyzyjnych po normalizacji.

Fig.14. Final vector of priorities.

Fig.14. Końcowy wektor priorytetów. 


\section{NEGATYWNE ODDZIALYWANIA NA PROCES REALIZACJI OBIEKTÓW PODZIEMNYCH W UJĘCIU WIELOKRYTERIALNEGO PODEJMOWANIA DECYZJI}

Keywords: studnia opuszczana, ściana szczelinowa, REMBRANDT, wielokryterialne wspomaganie decyzji, budowle podziemne

\section{SUMMARY :}

Główne konkurencyjne technologie dla obiektów podziemnych, to ściany szczelinowe i studnie opuszczane. W czasach współczesnych ściany szczelinowe realizowane są głównie dla obiektów wielkogabarytowych, a studnie opuszczane dla małogabarytowych. Obiekty tego typu projektowane są obecnie głównie dla oczyszczalni ścieków i zbiorników retencyjnych. Realizacja ich obejmuje niezwykle pracochłonne procesy. W trakcie wykonawstwa powstają nieprzewidziane oddziaływania negatywne. Podczas procesu budowy obiektów podziemnych najczęściej występują: odchylenia od pionu, zawisania, opuszczanie poniżej projektowanego poziomu, pękania, zarysowania, nieszczelności ścian. Celem pracy jest klasyfikacja niepożądanych oddziaływań negatywnych powstających w procesie realizacji obiektów podziemnych oraz wybór najkorzystniejszego rozwiązania technologiczno-materiałowego dla obiektów komunalnych. W charakterze aparatu matematycznego do zrealizowania tego zadania zostały wybrane metody wielokryterialnego podejmowania decyzji z uwzględnieniem ocen skutkowo- przyczynowych. Zastosowano metodę REMBRANDT (Ratio Estimation in Magnitudes or deciBells to Rate Alternatives which are Non-DominaTed). Badania dowiodły, iż ocena analityczna nieprzewidzianych oddziaływań negatywnych, sprzyjających sytuacjom awaryjnym w trakcie realizacji obiektów podziemnych jest możliwa przy wykorzystaniu metody REMBRANDT. 